\title{
CAPITAL WITHOUT WAGE-LABOUR: MARX'S MODES OF SUBSUMPTION REVISITED
}

\author{
Nicholas Vrousalis*
}

\begin{abstract}
This paper argues that capitalist social relations do not presuppose wage-labour. The paper defends a functional definition of the capitalist relations of production, in terms of what Marx calls the 'subsumption of labour by capital'. I argue that there are at least four modes of subsumption, one transitional to and one transitional from the capitalist mode of production. Unlike the capitalist mode of production, capitalist relations of production are compatible with the absence of a labour market, and even with the absence of workplace authority relations. The ambit of capitalist domination is therefore broader than typically thought.
\end{abstract}

Keywords: exploitation theory, historical materialism, Marxism, value-form theory, agrarian capitalism

Communism deprives no man of the power to appropriate the products of society; all that it does is to deprive him of the power to subjugate the labour of others by means of such appropriations.

\section{Marx and Engels, Communist Manifesto}

It is widely held that capitalist social relations are structurally individuated, that is, are uniquely coextensive with some set of property relations. There are capitalists, who own all of the means of production, and there are workers, who own none. This paper defends an alternative, functional definition of the capitalist relations of production, in terms of what Marx calls the 'subsumption of labour by capital'. Capitalist relations of production are not uniquely coextensive with some set of property relations. They are, rather, coextensive with the subsumption of labour by capital. I will argue that there are at least four modes of subsumption,

* Institute of Political Science, Leiden University, Wassenaarseweg 52, 2333AK Leiden, the Netherlands. Email: n.vrousalis@fsw.leidenuniv.nl 
one transitional to and one transitional from the capitalist mode of production. The mooted redefinition is philosophically significant, for it aligns the individuation of capitalist social relations with the ways that capitalists dominate workers. In other words, Marx's ubiquitous use of the terms 'subordination' (Unterordnung), 'subsumption' (Subsumtion) and 'domination' (Herrschaft) of labour by capital reflects forms of worker unfreedom.

The paper arrives at this functional definition by exploring the distinction between capitalist relations of production, on the one hand, and the specifically capitalist mode of production, on the other. There is an apparent inconsistency between Marx's discussion of capitalist relations of production as presupposing wage-labour in volume I of Capital, and his discussion of 'antediluvian forms' in volume III. Antediluvian capital, although a capitalist relation of production, does not presuppose wage-labour. I will show that the only consistent resolution of this putative contradiction rejects the volume I identification of capitalist social relations with wage-labour. It follows that capitalist unfreedom is not exhausted by the two modes usually associated with manufacturing and industrial capital, what Marx calls the 'formal' and 'real' subsumption of labour by capital. This has implications for the nature of self-employment, for the critique of market socialism, and for the understanding of the transition from feudalism to capitalism.

The paper is structured as follows. Section 1 sets out the conceptual landscape and offers some definitions. Section 2 elicits the contradiction between Marx's discussion of wage-labour in volume I of Capital and his discussion of antediluvian forms in volume III. Section 3 offers a resolution of the contradiction that drops wage-labour as a necessary condition for capitalist relations of production. Section 4 broaches and defends a related but distinctive form of subsumption that unites Marx's writings on cooperatives. Section 5 uses the distinction to develop a critique of market socialism. Section 6 discusses some implications of the functional definition for the connection between capital and class.

\section{DEFINITIONS}

I begin by sketching the orthodox definition of capitalist relations of production and the mode of production. I then offer tentative definitions of the concepts of subsumption and exploitation.

\subsection{Capitalist relations of production}

On an influential Marxist view, the relations of production are 'relations of effective power over persons and productive forces, not relations of legal ownership' (Cohen 2000: 63). An effective power is a nonnormative ability to effect outcomes. A taxonomy of effective powers à la Cohen 
permits a characterization of capitalist relations of production in terms of the subordinate producer's control over her labour power and means of production, as follows:

For any pair $\{r, s\}$, where $r$ and $s$ take their values from the set $\{A l l$, Some, None $\}, r$ represents the direct producer's degree of control over her own labour power, and $s$ over means of production. That the producer controls 'all' of her labour power entails that she enjoys a formal right of self-ownership, that is, is not liable to extra-economic coercion. On Cohen's orthodox view, the $\{$ All, None $\}$ set of powers is both necessary and sufficient for capitalist relations of production.

The orthodox view faces well-known objections. Take, for example, antebellum slavery in the American South. Cohen himself suggests that '[a] producer could be coerced into working for a wage and producing surplus value' (Cohen 2000: 83 refers to Marx 1976: 925). So antebellum slavery involves slaves performing wage-labour, but lacking full control over their labour power. That is, antebellum slavery provides a presumptive counterexample to the orthodox view (for a wealth of similar cases, see Banaji 2010). Consider, further, merchant and usury capital, the forms dubbed 'antediluvian' by Marx (1976: 266; 1981: 728). Under putting-out, for example, the merchant makes a profit by providing raw material to the peasant, buying the final product below its market value. Putting-out seems to be an instance of $\{A l l$, Some $\}$ relations of production, since the peasant must own some of the conditions of production. ${ }^{1}$ If putting-out betokens a capitalist relation of production - as I will argue below - then it constitutes another counterexample to the orthodox view.

This paper argues that, in light of these difficulties, it is preferable to define capitalist relations of production functionally. A relation $R$ is a capitalist relation of production if and only if $R$ involves relations of effective control over labour power and means of production that serve the subsumption of labour by capital. This definition makes $R$ compatible with any combination of the $r, s$ variables in the production relations set (whether or not it is represented in Table 1). Capitalist relations of production are then constituted by that subset of reproducible economic relations in which the extraction of surplus labour is subjected to the maximization of exchange value - or what Marx calls the 'law of value'. The connections between these concepts will, I hope, become more transparent in the discussion that follows.

1 The peasant must, however, lack comprehensive non-market access to the means of subsistence, which is what explains recourse to the merchant in the first place. See section 3 . 


\begin{tabular}{lll}
\hline & Labour power & Means of production \\
\hline Slave & None & None \\
Serf & Some & Some \\
Proletarian & All & None \\
Associated producer & All & All \\
\hline
\end{tabular}

TABLE 1. Relations of production (Cohen 2000: 65).

\subsection{The capitalist mode of production}

This paper defends a definition of capitalist social relations that draws upon Marx's distinction between the relations and the mode of production. Most discussions of Marx's theory of production note that he uses the term 'mode of production' in at least two senses, one narrow and one broad. In the narrow sense, the mode of production refers to the form of technology employed in production, including the technical division of labour. The narrow sense of the mode of production therefore excludes power relations. Here is an instance of this usage:

With regard to the mode of production itself, manufacture, in its strict meaning, is hardly to be distinguished, in its earliest stages, from the handicraft trades of the guilds, otherwise than by the greater number of workmen simultaneously employed by one and the same individual capital. (Marx 1976: 439. See also Marx 1976: 1026)

Handicrafts and manufacturing therefore share the same mode of production. Cohen (2000: 79-80) calls this the material mode. The broad sense of the mode of production, on the other hand, includes facts about the purpose of production and the form of social labour. Cohen calls this the social mode. For example:

The production of surplus-value, or the extraction of surplus labour, forms the specific content and purpose of capitalist production, quite apart from any reconstruction of the mode of production itself which may arise from the subordination of labour to capital. (Marx 1976: 411)

In what follows, I shall refer to the mode of production exclusively in the narrow, or material, sense. Marx usually relegates claims about the social mode, including claims about the power of capital over labour, to the mode of subsumption or subordination. ${ }^{2}$ This paper argues that Marx's mature works underwrite at least four modes of subsumption: hybrid, formal, real and abstract. Hybrid subsumption, on the one hand,

2 Marx uses the terms Subsumption and Unterordnung interchangeably; cf. Marx and Engels (1962: 199, 377, 533) and (1962: 354, 509, 533). 
represents the way capital dominates workers under usury, putting-out, and the so-called 'domestic system'. It is, in that sense, a 'transitional form' from feudalism to capitalism. Formal and real subsumption are explicitly discussed by Marx in Capital, volume I, and the Results of the Immediate Process of Production. Finally, abstract subsumption refers to the ways capital dominates workers under the cooperative factory. It is, in this sense, a transitional form from capitalism to communism.

\subsection{Exploitation and subsumption}

Consider, first, the subsumption of labour by capital. I assume that Marx's claims about subsumption entail the possession, by capitalists, of dominating power over workers. Domination obtains when a powerful agent, A, leads another agent, B, to act for reasons that are not independent of A's power. Suppose B is hungry. A uses her power, not in order to help $B$ act for hunger-based reasons (e.g. to eat because hungry), but rather in order to get $B$ to act for reasons based on A's power (e.g. to eat because otherwise A will beat B). Here A dominates B. The power of capital over labour is a form of dominating power, in the sense that it is a power compelling workers to act for power-dependent reasons. There are, after all, no reasons that workers should work for capitalists, other than those grounded on the power of the latter over the former. That power, in turn, obtains in virtue of capitalist control over the means of production. ${ }^{3}$

Now consider the exploitation of labour by capital. As a matter of conceptual necessity, A exploits B if and only if A presumptively benefits at B's expense by taking advantage of B. ${ }^{4}$ Marxists believe that the relevant metric of 'expense' is labour time. ${ }^{5}$ A extracts surplus labour from $B$ if there is an unequal exchange of labour time between $A$ and $B$, such that A pockets the difference. That is, A extracts surplus labour from B if: A's consumption bundle embodies $X$ hours of labour time, B's consumption bundle embodies $Y$ hours of labour time, whereas A's product embodies $Y$ hours, B's product embodies $X$ hours, and $X>Y \geqslant 0 .{ }^{6}$ A necessary condition for specifically capitalist exploitation is that surplus

${ }^{3}$ I defend these definitions and their moral implications in 'Reclaiming Domination', which is available from me upon request.

4 'Presumptively' because the benefit to A might not be realized: A steals B's wallet, which explodes in A's pocket. For a defence of the claims in the main text, see Wertheimer (1996: 209).

${ }^{5}$ Marx (1976) defines the 'labour embodied' in commodities counterfactually, as socially necessary labour time. What follows preserves that assumption.

${ }^{6}$ This unequal-exchange-of-labour definition is a generalization of Marx's account of the extraction of surplus-value. It is not to be confused with unequal exchange of value. The advantage of this definition is that it does not presuppose any theory of the determination of value, such as the labour theory of value. The best available axiomatic treatment of unequal labour exchange is Roemer (1982). 
labour assumes the value-form, that is, constitutes surplus value. I shall assume, throughout this paper, that what enables capitalist exploitation is the power of capital over labour. In a word, capitalist exploitation presupposes capitalist domination.

\section{INCONSISTENT DEFINITIONS}

This paper argues that capitalist relations of production, as valueconstituted relations of dominating power, extend well beyond the labour market. This section and the next discuss Marx's account of the relationship between capital and wage-labour. I begin by highlighting an apparent inconsistency in Marx's discussion of capitalist relations of production, drawing upon volumes I and III of Capital. In part II of volume I, Marx attempts to show that capitalist relations of production presuppose wage-labour. In part V of volume III, on the other hand, Marx argues that capitalist relations of production predate the capitalist mode of production, and therefore do not presuppose wage-labour. I will show that this inconsistency can only be resolved by dropping the presumptive volume I characterization of capitalist social relations. I now sketch the terms of this contradiction.

Many Marxists affirm the following two theses:

(1) Capitalist relations of production presuppose wage-labour, that is, the existence of a labour market. ${ }^{7}$

(2) Wage-labour presupposes capitalist relations of production.

The conjunction of these two claims entails the reciprocity thesis, according to which capitalist relations of production and wage-labour are extensionally equivalent. In what follows, I show, first, that Marx does not offer a deduction of (1), and second, that his discussion of antediluvian capital contradicts (1). For the purposes of this paper, I have no quarrel with (2).

\subsection{Marx's attempt to defend (1)}

In chapter 4 of Capital, volume I, Marx defines capital as 'self-valorizing value'. Capital is represented by the formula $M-C-M^{\prime}$, where $M$ and $M^{\prime}$ are money magnitudes, $C$ is a commodity, and $M^{\prime}>M$, such that $M^{\prime}$ involves newly created value (and is not a mere redistribution of

7 A 'wage-labourer', or proletarian, is any producer who, not owning any means of production, is 'free in the double sense that as a free individual he can dispose of his labour power as his own commodity, and that ... he has no other commodity for sale, i.e. he is ... free of all the objects needed for the realization of his labour power' (Marx 1976: 272-3). See Mandel (1974) and Cohen (2000) for refinements of this definition. 
value). Surplus value is defined as: $M^{\prime}-M=\Delta M$. According to Marx, capital assumes three main forms: merchant's capital, usurer's capital and industrial capital. Merchant's and usurer's capital are 'antediluvian' (Marx 1976: 266), in the sense that they 'appear before the modern primary form of capital' (Marx 1976: 267) Marx then argues that wage-labour is the only source of value. He does this by assuming an equivalence between prices and values. If that equivalence holds, then merchant and usury capital do not produce surplus value. Therefore only industrial capital produces surplus value. Chapter 6 of volume I completes Marx's argument, by showing that, on these assumptions, the only source of surplus value can be 'a commodity whose use-value possesses the peculiar property of being a source of value, whose actual consumption is therefore itself an objectification of labour, hence a creation of value' (Marx 1976: 270). That commodity is labour-power. Hence (1) holds. I now show that this argument fails on its own terms.

Marx's exposition has two parts. The first goes from a premiss about the definition of surplus value to a conclusion about merchant and usury capital, whereas the second goes from a premiss about value to a conclusion about the source of surplus value. The first part is as follows:

(3) The exchange of nonequivalents is never the source of newly-created surplus value, and always a mere redistribution of existing value. (Lemma)

(4) Merchant and usury capital presuppose exchange of nonequivalents. (Definition)

$\therefore$ (5) Merchant and usury capital 'appear impossible', that is, are mere redistributions of existing value.

Marx asserts (4) in Marx (1976: 266-7). ${ }^{8}$ Lemma (3) is the crucial move. It is formulated as follows: 'If equivalents are exchanged, no surplusvalue results, and if non-equivalents are exchanged, we still have no surplus-value' (Marx 1976: 266). What needs to be shown is that both sides of this biconditional hold: price-value nonequivalence must not only be necessary for mere redistribution of value, but also sufficient for it. But this is precisely what Marx does not show. That is, by Marx's own lights, some forms of merchant capital, such as putting-out, have a foothold in production. ${ }^{9}$ They do not, therefore, constitute mere redistribution of

${ }^{8}$ Note that these are just definitions. Usurer's interest, for example, represents an 'irrational price', that is, a magnitude not grounded on the value of some commodity (Marx and Engels 1989: 519). It follows that nonequivalence holds.

9 See Marx and Engels (1988: 30) for a discussion of surplus-value-producing merchant capital and Marx and Engels (1989: 519-20) for a discussion of surplus-value-producing usury capital. I substantiate this claim further below. 
existing value. In effect, Marx moves illicitly from the true claim that value redistribution is possible only if someone buys cheap and sells dear - that is, only if nonequivalence holds - to the false claim that nonequivalence is always value redistribution. This is important because, if (3) were true, then assuming equivalence would be tantamount to purging exchange of false positives: it would exclude merely redistributive exchanges. But if (3) is false, then assuming equivalence - as Marx proceeds to do in the second part of the argument - yields false negatives, that is, it excludes nonequivalent exchanges that do involve creation of surplus value. The false negatives are precisely those forms of merchant and usury capital that create surplus value. If Marx is taken to be offering a deductive argument, then he is not entitled to assume (3).

Having assumed the truth of (3), Marx asserts price-value equivalence. The second part of his argument is as follows:

(6) Equivalents are exchanged.

(7) If equivalents are exchanged, then the only source of surplus value, that is, the basis for the reproduction of capitalist relations of production, must be a commodity whose consumption creates value.

(8) That commodity is labour-power, and labour-power alone.

$\therefore$ (1) Capitalist relations of production presuppose wage-labour.

Suppose (8) is granted. ${ }^{10}$ The argument still begs the question. That is, (6) covertly assumes the truth of (1). For consider: by (3) and (4), merchant and usury capital do not produce surplus value. But then to affirm (6) is to assume that only industrial capital produces surplus value. And since industrial capital and wage-labour are extensionally equivalent, (1) follows without the help of auxiliary premiss (7). The second part of the argument is redundant. Chapters 4-6 of volume I therefore amount to little more than further clarification of Marx's assumptions - as opposed to a nontrivial deduction of (1) from independent axioms. ${ }^{11}$ Indeed, Marx's dropping the assumption of equivalence in volume III of Capital makes (6) false and the putative derivation of (1) invalid. No deduction of (1) is ever provided.

${ }^{10}$ Roemer (1996) and Wolff (1985) have shown that (8) holds only on the questionable assumption that the value numeraire is labour time, and not some other arbitrarily chosen unit.

11 This case has been made eloquently and effectively by Gil Skillman, in a series of important papers (Skillman 1996, 1999, 2007). Skillman's work provides the impetus for much of the discussion that follows. 


\subsection{Cohen's attempt to defend (1)}

It is worth considering another influential, but equally invalid, defence of (1). Consider the following famous passage from the Grundrisse:

The concept of capital implies that the objective conditions of labour ... acquire a personality as against labour, or, what amounts to the same thing, they are established as the property of a personality other than the worker's. The concept of capital implies the capitalist. (Marx 1973: 512)

Cohen claims that the last sentence of this passage 'is, in fact, a compressed statement of thesis [(1)]' (Cohen 2000: 184, n. 2). The idea here is that, since capital implies the 'personification' of the conditions of labour in the capitalist, the existence of the capitalist implies the existence of the wagelabourer. This inference is invalid: the objective conditions of labour can acquire a 'personality as against labour' if capitalists merely hire them out to workers (through lending, for example), as opposed to hiring workers in to use them. Whether capital hires labour or labour hires capital, it is still the 'objective conditions of labour' that dominate workers. ${ }^{12}$ The same invalid inference, from Marx's assertions about the alienated form of social relations to the existence of wage-labour, pervades the works of Sweezy (1942), Mandel (1974), Fine and Saad-Filho (2004), Harvey (2010), Callinicos (2014), among many others. ${ }^{13}$

Again, no valid deduction of (1) has been provided.

\subsection{The locus of the inconsistency}

I now locate the apparent inconsistency in Marx's writings. In chapter 36 of volume III of Capital, Marx distinguishes between two forms of usury: lending money to 'extravagant magnates' for the consumption of luxuries and lending to 'small producers who possess their own conditions of labour' (Marx 1981: 729). The latter form of usurer's interest, he suggests, represents surplus value. Marx then distinguishes usury (or interestbearing) capital under the pre-capitalist mode from the form it assumes under the capitalist mode of production (Marx 1981: 730). In a famous passage, he argues that:

Usurer's capital, in this form where it actually appropriates all the surplus labour of the direct producer, without altering the mode of production; where the producers' ownership or possession of their conditions of labour

${ }^{12}$ For a formal treatment, see the isomorphism theorem in Roemer (1982: 89-95).

${ }^{13}$ It is not, of course, possible that all capitalists become money capitalists. Marx points out that this would lead to a 'tremendous fall in the rate of interest' (Marx 1981: 501), forcing some money capital into industry. The question is whether one can move from a premiss about the alien conditions of labour to the presence of wage-labour. And this is precisely what these authors do not show. 
... is an essential precondition; where capital therefore does not directly subordinate labour, and thus does not confront it as industrial capital this usurer's capital impoverishes the mode of production, cripples the productive forces .... and simultaneously perpetuates these lamentable conditions in which the social productivity of labour is not developed ... as it is in capitalist production. (Marx 1981: 730-1)

Several things follow. First, capitalist relations of production pre-date the capitalist mode of production. Second, those direct producers subsumed under usury capital are subject to $\{$ All, Some $\}$ relations of production (see Table 1). They differ, in that respect, from the industrial proletarian. Third, it is false that usury capital does not subordinate labour: Marx asserts that it merely fails to 'directly subordinate labour' (my emphasis). Indeed, he later adds that '[u]surer's capital has capital's mode of exploitation without its mode of production' (Marx 1981: 732). In the next section, I show that this 'indirect' subordination of labour by usury capital is tantamount to capitalist domination of the producer as such, only outside the factory.

Marx therefore thinks that usury capital, insofar as it appropriates newly created value, is a capitalist relation of production; it entails a relationship of dominating power geared towards the production of surplus value, not its mere redistribution. ${ }^{14}$ Similar considerations apply to merchant capital: putting-out, for instance, has a similar exploitative structure.

Now consider the following triad of claims:

(1) Capitalist relations of production presuppose wage-labour.

(9) Merchant and usury capital constitute capitalist relations of production.

(10) Merchant and usury capital do not presuppose wage labour.

The triad is inconsistent; no more than two of its claims are simultaneously assertable. In volume I of Capital, Marx seems to be deducing (1). In volume III he asserts the conjunction of (9)-(10). The next section makes the case for keeping the conjunction. If that case is sound, then (1) must be false. The upshot is that capital dominates workers in a variety of ways, wage-labour being only one of them.

${ }^{14}$ Marx's discussion of the Indian usurer is relevant here. He writes that the usurer 'extorts ... surplus value' by charging interest to the peasant (Marx 1976: 1023). But then usury capital does not have a merely redistributive function; it is productive of surplus value and therefore constitutes a capitalist relation of production. This point is also made by Banaji, who argues that 'the price [Indian peasants receive from usury capitalists] is no longer a pure category of exchange, but a relation of production' (Banaji 1975: 1891). 


\section{RESOLVING THE INCONSISTENCY}

Volumes I and III of Capital provide apparently inconsistent definitions of capitalist social relations. To defend the Marxian position, then, one must criticize it. The only consistent reading, I think, interprets part II of volume I as abstracting from anything but industrial capital in its pure form. This is a methodologically acceptable working assumption. On this interpretation, Marx's argument in chapters 5-6 of volume I criticized in section 2 above - does not offer a deduction of wage-labour as the source of value. Rather, Marx offers an elaboration of the analytical connections between the categories already canvassed in chapters 1-4, which presuppose wage-labour as the sole source of value. The putative contradiction between volumes I and III then disappears, for the working assumption of pure industrial capital is dropped well before Marx's volume III discussion of antediluvian capital. If this interpretation is sound, then it follows that Marx extends the purview of capitalist relations of production beyond wage-labour. The rest of this section defends this reading, by focusing on capitalist social relations that historically precede the capitalist mode of production.

\subsection{Skillman on subsumption}

It is well-known that Marx posited an important distinction between manufacturing and mechanized industry, discussed with consummate brilliance in chapters 14 and 15 of Capital, volume I. The distinction is between the formal and real subsumption of labour by capital. Under the former, often identified with manufacturing, the technical basis of the mode of production has not yet 'become adequately realized - it [has] not become indispensable, and that also means technologically indispensable' to 'producing for the sake of production' (Marx 1976: 1037-38). According to Marx:

from the standpoint of the purely formal relation - the general form of capitalist production, which is common both to its less developed stage and to its more developed stage - the means of production ... do not appear subsumed to the labourer, but the labourer appears subsumed to them.

(Marx 1969: 390)

The 'less developed' stage of 'capitalist production' is formal subsumption; the 'more developed' real subsumption. To these different modes of subsumption there correspond different forms of surplus value (what Marx calls 'absolute' and 'relative' surplus value) and different degrees of worker independence. Crucially, however, both formal and real subsumption presuppose a complete separation of the worker from the means of production. That is, they are characterized by $\{$ All, None $\}$ relations of production, the set of property relations uniquely coextensive 
with wage-labour. The obverse of this separation is that dark archetype of modernity, the factory. ${ }^{15}$

This taxonomy is incomplete. For, as the discussion in chapter 36 of volume III shows, Marx manifestly believes that capitalist relations of production precede the factory. Indeed, it is incoherent to think that capitalist relations of production can 'transform' or 'penetrate' a mode of production without predating its transformed successor. Marx writes, moreover, that the 'reproduction of the handicraft system on the basis of machinery only forms a transition to the factory system' (Marx 1976: 589 ) and refers to the 'medley of transitional forms' from handicrafts to manufacturing (Marx 1976: 602). He adds:

It will be sufficient if we merely refer to certain hybrid forms [Zwitterformen], in which although surplus labour is not extorted by direct compulsion from the producer, the producer has not yet become formally subordinate to capital. In these forms, capital has not yet acquired a direct control over the labour process. (Marx 1976: 645)

It follows that 'transitional' and 'hybrid' forms represent 'indirect' modes of subsumption of labour to capital. That is, they constitute capitalist relations of production transitional to the capitalist mode of production. Skillman (2007) offers a helpful taxonomy of these hybrid forms. He uses Marx's expanded schema of the capital circuit: $M-C \ldots P \ldots C^{\prime}$ - $M^{\prime}$, where ...P... represents the production of new value, with two modifications. The first modification uses arrows to represent the transformation of value-adding inputs into outputs, such that Marx's schema now appears as $M-C \rightarrow P \rightarrow C^{\prime}-M^{\prime}$. The second modification uses brackets to characterize the portion of the labour process that remains in the control of the worker. Skillman's schema is depicted in Table 2.

The first row represents usury capital: the usurer advances money capital $M$ to the direct producer, who uses it to buy commodities worth $C$. The producer then adds value, turning $C$ to $C^{\prime}$, which she sells for $M^{\prime}$. She then uses the proceeds to pay interest to the usurer. Crucially, the producer retains some degree of control over her product, over the labour process, and over the process of circulation. A typical complement to this autonomy is the producer's possession of certain means of production, tools and so on, some of which are used as collateral for the loan.

${ }^{15}$ Murray (2004) makes a cogent case for the view that Marx's modes of subsumption are not historical, but systematizing categories. He then argues that the division of labour and manufacturing are both forms of real, not merely formal, subsumption. The latter claim contradicts my cut between formal and real subsumption. Murray's cut, even if sound, has no bearing on my case against (1), or on the nature of the transitional forms flanking formal and real subsumption.

16 The hybrid forms are also discussed under the name 'transitional forms' [Uebergangsformen] in Marx's 1861-3 manuscripts. See Marx and Engels (1994: 117-121). 


\begin{tabular}{lll}
\hline & Capital circuit & Mode of subsumption \\
\hline Usurer & $M-\left\{M-C \rightarrow P \rightarrow C^{\prime}-M^{\prime}\right\}-M^{\prime}$ & Hybrid \\
Merchant & $M-C-\left\{C \rightarrow P \rightarrow C^{\prime}\right\}-C^{\prime}-M^{\prime}$ & Hybrid \\
Manufacturer & $M-C \rightarrow\{P\} \rightarrow C^{\prime}-M^{\prime}$ & Formal \\
Industrialist & $M-C \rightarrow P \rightarrow C^{\prime}-M^{\prime}$ & Real \\
\hline
\end{tabular}

TABLE 2. Skillman's taxonomy.

The second row represents merchant capital: the merchant uses money capital to purchase raw materials worth $C$. The merchant then gives these raw materials to the producer, who valorizes $C$ to $C^{\prime}$, which is then appropriated by the merchant and sold for $M^{\prime}$. This is, for example, how the capitalist dominates the producer under putting-out. ${ }^{17}$ Skillman (2007) calls the subsumption obtaining under merchant capital primitive subsumption. I here follow Marx in calling it hybrid. ${ }^{18}$

The third and fourth row represent formal and real subsumption, respectively. Under formal subsumption, the worker still retains a modicum of autonomy because the labour process has not been completely objectified: the manufacturing worker is still 'a fragment of his own body' (Marx 1976: 482), but not yet a mere 'living appendage' of the machine (Marx 1976: 548). This modicum of autonomy is represented in the third row by the worker's control over the labour process, which is completely forsaken under mechanized industry. The move downwards along this table, from usury to industry, schematically represents the thinning out of producer autonomy, together with the corresponding extension of capital's domination of the producer. Skillman's elegant taxonomy thus vindicates the developmental continuity between hybrid, formal and real subsumption as capitalist relations of production. It thereby vindicates (9), the view that merchant and usury capital constitute capitalist relations of production.

I turn now to (10), which says that one can have hybrid subsumption of labour to capital without wage-labour, indeed without a labour market. Suppose that (10) is false. That is, suppose that putting-out presupposes the existence of a labour market. Now the putter-out optimizes by hiring a proletarian. This reduces monitoring, waste and pilfering costs, assuming that the cost of monitoring effort is not excessively high. But then putting-out is unprofitable; labour markets imply the euthanasia of the

17 On putting-out see Marglin (1974) and more recently Ogilvie (2008).

18 Skillman (2007) does not include usury capital under hybrid subsumption because it does not involve direct control over the producer's surplus. But since usury does involve the subsumption of labour under the circuit of capital, and since it is, like merchant capital, an extra-factory phenomenon, I will assume that hybrid subsumption also applies to usury. 
putter-out. This contradicts the anti-(10) assumption that being a putterout is profitable when wage-labour is available. ${ }^{19}$ This simple argument shows why labour markets presuppose an $\{$ All, None $\}$ set of relations of production, rendering them incompatible with putting-out. As Skillman points out, the historical survival of antediluvian forms of subsumption largely depended on producers' nonmarket access to nonlabour collateral, mainly land. The gradual erosion of that collateral led to the eventual demise of hybrid subsumption and ushered in the era of the factory (see Marx 1981: 730-1). Hence hybrid subsumption does not entail wagelabour. Therefore (10) holds. Given the truth of (9), it follows that (1) is false.

\subsection{Banaji on subsumption}

Like Skillman, Jairus Banaji has recently argued that antediluvian capital constitutes capitalist relations of production. Banaji offers numerous penetrating historical studies of these relations, from early Byzantium to contemporary India. Banaji's studies also vindicate (9). In discussion of the relationship between big, middle and proletarianized peasantry in the mid-19th century Deccan districts of India, Banaji writes:

the extortion of surplus-labour as surplus-value, is not sufficient to constitute [formal] subordination. Thus, a monied capitalist (for example, a merchant, moneylender) may dominate the small producer on a capitalist basis, he may, in other words, extort surplus-value from him, without standing out as the "immediate owner of the process of production"... Clearly, such a system, a 'preformal' subordination of labour to capital, would tend to lead in the majority of cases to the system of formal subordination ... there might be historical situations where in the absence of a specifically capitalist mode of production on the national scale, capitalist relations of exploitation may nonetheless be widespread and dominant. (Banaji 2010: 281-2)

Banaji's 'pre-formal subordination' is equivalent to Skillman's 'primitive' subsumption, both of which are equivalent to what Marx calls hybrid

${ }^{19}$ An anonymous referee points out that the putative inverse relationship between profitability and worker autonomy may no longer hold, indeed may never have held. There are theoretical reasons to think this, based on incomplete contracts, efficiency wages, and so on. Moreover, the putative inverse relationship fails to explain the persistence of subcontracting and horizontal hierarchies, among other things. A comprehensive response would, I assume, study the conditions for the emergence of hierarchies in specific industries, along the lines suggested by Rajan and Zingales (2001). All I can do here is refer to the evidence adduced by Marglin (1974), Skillman (2007) and Ogilvie (2008), as to the relative cost-effectiveness of wage labour in Marx's time. 
subsumption. ${ }^{20}$ It follows that Banaji affirms (9): merchant and usury capital sometimes constitute capitalist relations of production. ${ }^{21}$

But unlike Skillman, Banaji baulks at (10), preferring variations on (1) instead. In response to the charge that antediluvian forms of capital do not involve wage-labour, Banaji replies that they entail 'disguised wagelabour'. He writes, for example:

instead of seeing wage-labour as one form of exploitation among many, alongside sharecropping, labour tenancy, and various kinds of bonded labour ... these 'forms' may reflect the subsumption of labour into capital in ways where the 'sale' of labour-power for wages is mediated and possibly disguised. (Banaji 2010: 145)

This attempt to defend (1) is incoherent. ${ }^{22}$ For if usury and merchant capital entail wage-labour, disguised or not, then they (trivially) presuppose industrial production. The point of distinguishing sharply between hybrid and formal subsumption, however, is to show how, in the manner of Skillman, the factory constitutes a turning point in the economic articulation of modernity. The factory presupposes an all $\{$ All, None\} set of production relations, that is, the 'complete expropriation' of the producer. This is not the predicament of the producer under putting-out or usury, as Banaji's own studies show. In other words, if 'pre-formal' subsumption entails 'disguised' wage-labour, then Banaji's distinction between formal and preformal subsumption - indeed, the whole edifice of distinctions between a 'dependent middle peasantry' and a 'semi-wage-labour peasantry' (Banaji 2010: 317-323) - collapses. ${ }^{23}$ Banaji should, in all consistency, embrace (10) and reject (1). Capitalist relations of production do not presuppose commodified labour-power, or even workplace authority relations.

${ }^{20}$ Rakesh Bhandari is therefore mistaken when he claims that 'Banaji counts as formal subsumption usurious or mercantile appropriation of surplus-value from atomised peasants and craftsmen' (Bhandari 2008: 87). Banaji explicitly distinguishes between preformal and formal subsumption, attaching usury and merchant capital to the former.

${ }^{21}$ It also follows from the passage just cited that, unlike what some of his critics have maintained (for example, Post 2013), Banaji's argument does not contradict the Brenner thesis. According to Brenner (1976), the capitalist mode of production first arose in England because the nature of class relations in 17th century England was both necessary and sufficient for that mode. But now note that this thesis is perfectly compatible with Banaji's claim that capitalist relations of production pre-date the capitalist mode of production. Indeed, Brenner himself admits as much in his discussion of transitional forms (Brenner 1977: 52, n. 43). I discuss Brenner and Post further below.

22 It is also inconsistent with Marx's writings on the topic. See, for example, Marx (1981: 730), where the 'wage-slave' and the 'debt-slave' are explicitly contrasted.

${ }^{23}$ As Banaji himself shows, Lenin's attack against the Narodniks (on the capitalist nature of Russian agriculture) only makes sense on the assumption that capitalist relations of production do not presuppose a labour market (Banaji 2010: 50-1); that is, only if (10) holds. In his debate with the Narodniks, Lenin had to reject (1). 


\subsection{Brenner and Wood on subsumption}

I now consider an influential account of the transition from the precapitalist to the capitalist mode of production. This account posits the extraction of surplus labour in the value form as a necessary but not sufficient condition for the subsumption of labour by capital. On this view, the set of sufficient conditions is completed by the existence of a specific form of relationship between markets and producers.

Robert Brenner has argued that capitalist relations of production presuppose market dependence on the part of both capitalists and producers. It is the asymmetric nature of that dependence that explains the rise of English agrarian capitalism. Indeed, market dependence is Brenner's explanation for the secular growth of agricultural productivity in early modern England, largely accounting for its early industrialization (Brenner 1976, 1977). E.M. Wood elaborates:

Economic units could be market-dependent - that is, separated from nonmarket access to the means of their self-reproduction - without being completely propertyless and even without employing propertyless wage labourers. (Wood 2002: 51)

Since, according to Brenner and Wood, these forms of market dependence constitute capitalist relations of production, the Brenner/Wood account contradicts the orthodox definition of capitalist social relations. Indeed, it entails the falsehood of (1). But what exactly is 'market-dependence'? Here is a typical formulation, due to Charles Post:

If the continued possession of land and tools for non-producers and access to consumer goods for direct producers ... does not depend upon successful market competition, then the law of value does not operate and the unique dynamics of capitalism (specialization, technical innovation and accumulation) do not pertain. ${ }^{24}$

By 'law of value' Post means the imperative to produce commodities at 'socially necessary labour time' - roughly cost of production - thereby maximizing exchange value. ${ }^{25}$ There are three different, and progressively narrower, senses of market-dependence in Post's definition: (a) The broadest sense refers to lack of nonmarket access to the means of subsistence and production. (b) A narrower sense refers to subjection to market competition and the law of value. (c) A yet narrower sense refers

24 Personal communication, 29.3.16. Post (2011: 23-4) similarly defines capitalist social relations in terms of 'enforced dependence' and 'subordination ... to the law of value'.

25 These commodities need not include labour-power. To assume this is tantamount to the same petitio principii criticized in section 2. 
to subjection to market competition that leads to 'specialization, technical innovation, accumulation'. ${ }^{26}$

For our purposes, (b) offers the best specification of marketdependence. On the one hand, (a) is too broad: on this definition, the monopsonistic feudal lord, or Marx's 'extravagant magnate', who lacks nonmarket access to grain, is market-dependent. (c), on the other hand, is too narrow. For on this definition, the pre-revolution agriculture of Russia (Lenin's agrarian capitalism), the Deccan capitalism of Banaji, the decadent industries of 'actually-existing socialism', and many other instances of - presumptively capital-positing - backwardness involve noncapitalist relations of production. Market-dependence is therefore best defined in terms of subjection to the law of value, but not the possible effects of that law.

In light of these amendments, subsumption - and by extension capitalist relations of production - can now be defined as the production of surplus labour, subjected to the imperative of cost minimization, and extracted by exploiters in the value form. This definition has important implications. It implies, for example, that all forms of petty commodity production - self-employment, family farms, agricultural cooperatives, etc. - that are both exploited and subjected to the imperatives of profit maximization, involve subsumption of labour to capital. It follows, again, that capitalist relations of production do not presuppose a labour market; capital-subsumed self-employment is not a kind of wage-labour. By the same token, the petty commodity production of 17th-century middle English peasants (Byres 2006), or of 19th-century American family farms (Post 2011), betoken capitalist relations of production.

I now show that this definition of subsumption implies that market socialism represents yet another, distinctive, form of subsumption of labour by capital.

\section{ABSTRACT SUBSUMPTION}

This section argues that there is another (transitional) mode of subsumption, one that Marx left almost completely unexplored, save for some suggestive remarks in volume III of Capital. Unlike antediluvian subsumption, which bridges feudalism and capitalism, the 'postdiluvian' form bridges capitalism with communism. I proceed as follows: first, I show that Marx does indeed think there is a set of capitalist relations of production that provide such a bridge. I then offer an argument that this set of relations engenders a mode of subsumption distinct from the ones canvassed so far: hybrid, formal, real. The argument, roughly, is

26 Similar vacillation about the exact nature of dependence pervades Wood (1999) and Wood (2002). 
that if petty commodity production can be subsumed by capital through market dependence on usurers or merchants, then it can be subsumed by capital through market dependence tout court, that is, without usurers or merchants. In other words, capital can subsume labour through mere exchange. This mode of subsumption I call abstract subsumption.

\subsection{Cooperatives as a transitional form}

In discussion of cooperative factories, Marx writes:

These factories show how, at a certain stage of development of the material forces of production, and of the social forms of production corresponding to them, a new mode of production develops and is formed naturally out of the old. Without the factory system that arises from the capitalist mode of production, cooperative factories could not develop. Nor could they do so without the credit system that develops from the same mode of production. This credit system, since it forms the principal basis for the gradual transformation of capitalist private enterprises into capitalist joint stock companies, presents in the same way the means for the gradual extension of cooperative enterprises on a more or less national scale. Capitalist joint-stock companies as much as cooperative factories should be viewed as transition forms from the capitalist mode of production to the associated one, simply that in the one case the opposition is abolished in a negative way, and in the other in a positive way. (Marx 1981: 571)

The putative connections between the 'cooperative enterprise' and the 'capitalist joint stock company' are opaque unless juxtaposed with Marx's critique of the ideological conflation of 'profits of management' with 'wages of supervision':

With the development of cooperatives on the workers' part, and joint-stock companies on the part of the bourgeoisie, the last pretext for confusing profit of enterprise with the wages of management was removed, and profit came to appear in practice as what it undeniably was in theory, mere surplusvalue, value for which no equivalent was paid. (Marx 1981: 513-14)

This contrast is further illuminated by Marx's famous orchestra analogy:

A musical conductor need in no way be the owner of the instruments in his orchestra, nor does it form part of his function as conductor that he should have any part in paying the 'wages' of the other musicians. Cooperative factories provide the proof that the capitalist has become just as superfluous as a functionary in production as he himself, from his superior vantage point, finds the large landlord. (Marx 1981: 511)

Through a characteristically Marxian dialectic of self-abolition, the capitalist system generates a credit system, which makes possible the separation of ownership from control, which, if realized, paves the way for worker-controlled factories under a system of social ownership 
of the means of production. ${ }^{27}$ Suppose all factories were turned into cooperatives. Surely that would suffice to abolish the domination of labour by capital. But then worker-controlled, socially owned, market-operating cooperatives are not a mere transitional form towards socialism; they are socialism. Marx rejects this conclusion. He writes:

The cooperative factories run by workers themselves are, within the old form, the first examples of the emergence of a new form, even though they naturally reproduce in all cases, in their present organization, all the defects of the existing system, and must reproduce them. But the opposition between capital and labour is abolished here, even if at first only in the form that the workers in association become their own capitalist, i.e. they use the means of production to valorize their own labour. (Marx 1981: 571)

Like hybrid subsumption, abstract subsumption is a transitional form. There is much debate as to exactly what Marx means by 'workers' becoming 'their own capitalist'. ${ }^{28}$ But the conjunction of this passage with passages where Marx claims that both workers and capitalists are dominated under capitalism (see, for example, Marx 1976: 990), seems to entail that the reciprocal pressures of competition cause workers-turnedcapitalists to suffer some form of domination, or 'enslavement' even where all factories are profit-maximizing cooperatives. Is this claim defensible? It is, I believe, defensible, but not for the widely held reason that marketoperating cooperatives 'self-exploit'. ${ }^{29}$ The next section refutes the 'selfexploitation' claim and suggests a reading of what 'valorize their own labour' means, one based on the abstract subsumption of labour to capital.

\section{THE CASE AGAINST MARKET SOCIALISM}

\subsection{Self-exploitation}

Market socialism has been proposed as a half-way institutional remedy to exploitation of all forms that is neither based on central planning, nor is exclusively laissez-faire. In models of market socialism the basic idea is captured by a decentralised form of worker management based on

27 Marx (1981: 503) draws a distinction between the capitalist as owner and as function. In the former role, the capitalist earns a return equal to the rate of interest. In the latter role, she organizes production and thereby earns a return in excess of the rate of interest. According to Marx, the existence of joint stock companies is evidence that the capitalist is no longer indispensable in her performance of the functional role.

28 See, for example, Lebowitz (2010) and Jossa (2012).

${ }^{29}$ Another common Marxist reaction is to treat this as a variant of petty commodity production and then dismiss it as economically unstable (see, for example, Mandel 1974: 7-41; Cohen 2000: 186). But Marx does not say that workers become their own capitalists after competing cooperatives go bankrupt; they become capitalists the moment they 'use the means of production to valorize their own labour'. The question of instability is neither here nor there. 
profit maximization, in which: (a) the means of production are jointly owned (either by workers, or by the state), (b) firms are democratically controlled by the workers in the firm, allowing them to share in the profit, and (c) production is for a market, in which values are determined by average or marginal cost. Economic democracy of the market socialist variety achieves inter-firm equilibrium through maximization of profit: the individual firm's maximand is revenue per worker. Thus in long-run competitive equilibrium the firms that survive are those, and only those, that make an economic profit greater than, or equal to, zero. ${ }^{30}$

A common complaint levelled against market socialism is that it encourages the 'self-exploitation' of workers. The idea seems to be that, since capitalists exploit workers, and all workers are capitalists, capitalist-workers exploit capitalist-workers, i.e. capitalistworkers exploit themselves. ${ }^{31}$ This complaint is incoherent, for two reasons. As a matter of conceptual necessity, to exploit is to benefit at someone else's expense. It follows that A cannot exploit A, and that A cannot exploit B if A does not extract a presumptive net benefit from some transaction with B. So even if it did make sense to say that workers somehow harm or degrade themselves under market socialism, it would still be false that they self-exploit.

\subsection{The real case against market socialism}

Suppose there is a system of commodity production without a labour or a credit market. Under such a market system, different firms will come to own differential assets, depending on how successful they are at accumulating capital. The whole point of allowing the existence of profit-seeking firms, after all, is to take advantage of the coordinating informational signals putatively furnished by competitive markets. Now, some firms will do badly and will have to lay people off. Others will do well and will need to hire people. More successful firms will accumulate more wealth. It is a short step from this inequality to the claim that the member of firm A can exploit the member of B. Here is one way this can happen, in the absence of A hiring B, or indeed of any kind of labour market:

There are two producers, Friday and Robinson. Friday is wealth-poor, Robinson is rich. If they do not trade, Robinson will work 8 hours and

30 The most well-developed account of workers' cooperatives under market socialism is due to David Schweickart. See Schweickart $(1996,2011)$.

31 This complaint does not describe intra-firm exploitation, for example the exploitation of cooperative workers by cooperative managers. Rather, the idea is that a capital-subsumed economic unit can exploit itself even if it has only one member. Post (2011: 28) attributes self-exploitation to petty commodity producers - competition-subsumed individuals or family farms - in the antebellum USA. 
Friday will work 16, so that each can satisfy his needs (assuming they're both rational, the fact that they decide to trade shows that they both benefit from trading). They only trade in final goods, and there are no labour or credit markets. In equilibrium under free trade, Friday works 12 hours, Robinson works 4 , and both attain subsistence. ${ }^{32}$

Roemer claims, and Marx agrees, ${ }^{33}$ that there is exploitation here. Indeed, as long as Friday appropriates the surplus in value-form, there is extraction of surplus value: having worked for 4 hours, Robinson can relax for the rest of the day, while Friday toils to produce what Robinson would otherwise have produced only with an extra 4 hours of work. Hence:

Robinson benefits from Friday's presence, and is able to use his wealth as leverage, through the market, to get Friday to work for him, which Friday would not have to do if he had access to his per capita share of the produced capital. (Roemer 1996: 52)

Note that this exchange, insofar as it is subject to the law of value, is a capitalist relation of production. I now want to argue that such exploitative transactions, obtaining through mere trade in goods and in the absence of labour and credit markets, constitute abstract subsumption. Subsumption, I said at the outset, is a freedom term: it describes the way capital dominates labour. In the present example, Robinson clearly possesses a power over Friday, indeed more power than Friday possesses over Robinson (notice Roemer's claim that Robinson can 'get Friday to work'). The evidence for this is the discrepancy in the number of hours worked. It is, moreover, in virtue of that power that Friday has a reason to work for Robinson: in equilibrium Friday acts as Robinson's unhired servant. So their relationship is one of domination. This form of domination falls under abstract subsumption in the sense that, unlike formal and real subsumption, it does not depend on the existence of a labour market and, unlike hybrid subsumption, it does not depend on the existence of a credit or money market. And yet the relationship engenders extraction of surplus labour - not mere value-redistribution - subjected to the law of value. This capitalist relation of production is, for all present purposes, abstract.

It is, now, but a short step to show that market socialism involves abstract subsumption. For cooperatives, even the most successful ones, will need access to raw materials, machinery and other objective

32 This example is adapted from Roemer (1996: 52-53). See also Roemer (1988: 101-3) for a formal axiomatic treatment.

33 'The relationship between labour days of different countries may be similar to that existing between skilled, complex labour and unskilled, simple labour within a country. In this case, the richer country exploits the poorer one, even where the latter gains by the exchange' (Marx 1972: 106). It follows that the rich can exploit the poor in the absence of a labour or credit market. 
conditions of labour. Under market socialism, by assumption, these can only be purchased from other cooperatives. As the process of accumulation proceeds, more successful cooperatives will accumulate wealth, which will eventually manifest itself in unequal exchanges of the Friday-Robinson variety. ${ }^{34}$ Such exchanges are capital-positing, insofar as they involve the extraction of surplus value subject to the law of value. It follows that such exchanges involve abstract subsumption. I now argue that this form of subsumption finds corroboration in Marx's mature published writings.

\subsection{Abstract subsumption in Marx}

In volume III of Capital Marx introduces the famous 'transformation problem' of dealing with the transformation of values into prices. Although this problem is beyond the scope of this paper, Marx's solution has some bearing on whether he thought abstract subsumption possible. I now argue that Marx's proposed solution - whether sound or not - provides a Robinson-Friday-type mechanism of exploitation of cooperatives by cooperatives.

The transformation problem arises because different capitalist firms or industries have different organic compositions of capital. ${ }^{35}$ If prices and values are assumed equivalent and if the ratio between surplus value and the wage bill is assumed constant - Marx calls this ratio the rate of exploitation - then firms with higher than average organic composition (call them $F_{\text {high }}$ ) will tend to earn lower than average profits, whereas firms with lower than average organic composition (call them $F_{\text {low }}$ ) higher than average profits. But if there is a uniform rate of profit, which Marx (1981: 254-301) assumes, then the excess surplus value extracted in $F_{\text {low }}$ will be redistributed from $F_{\text {low }}$ to $F_{\text {high }}$ until profit rates are equal. The only way this transfer can be effected is if relative prices satisfy: $p_{F_{h i g h}} / p_{F_{\text {low }}>1}$. This, in turn, implies that relative prices will not be equivalent to relative values. The set of prices formed out of the equalization of the rates of profit Marx calls prices of production.

34 The success of some cooperatives will sometimes depend solely on the superior talents of their members. When that happens, abstract subsumption obtains due to mere talent inequality, or, more generally, what Roemer (1988) calls inequality of inalienable assets. This inequality can be ameliorated through asset redistribution, along the lines suggested by Dworkin (2000).

${ }^{35}$ Marx distinguishes between the technical, the value and the organic composition of capital. The technical composition is simply the ratio of the mass of the means of production to the mass of labour necessary to set them into motion. The value composition is the value of the means of production, or constant capital, over the value of labour power, or variable capital. The organic composition is the value composition expressed as an increasing function of the technical composition (Marx 1976: 762-3). See Howard and King (1975: 196-8) for a simple model. 
Marx's argument implies that $F_{\text {high }}$ extracts surplus value from $F_{\text {low }}$ à la Roemer: capital-intensive cooperatives exploit labour-intensive cooperatives. This is the Friday-Robinson-type mechanism we were looking for, which corroborates the abstract subsumption view.

However, some of Marx's writings seem to contradict this conclusion. In his discussion of Wakefield's theory of colonization, for example, Marx writes:

the means of production and subsistence, while they remain the property of the immediate producer, are not capital. They only become capital under circumstances in which they serve at the same time as means of exploitation of, and domination over, the worker. (Marx 1976: 933)

Since cooperatives are the property of the immediate producers, it seems to follow from this passage that cooperative worker-owners cannot be 'their own capitalist'. Defenders of market socialism, such as DiQuattro (2007) take passages such as this to corroborate their view that market socialism cannot involve exploitation. This inference is too quick. For Marx's discussion, in this context, manifestly relies on a premiss about the relative scarcity of labour-power relative to land:

The essence of a free colony ... consists in this, that the bulk of the soil is still public property, and every settler on it can therefore turn part of it into his private property and his individual means of production, without preventing later settlers from performing the same operation. (Marx 1976: 934)

What advocates of market socialism need to show is that, under a system of competing cooperatives, the 'bulk' of capital is 'public property', in the sense that one's appropriation of the means of production does not 'subjugate the labour of others by means of such appropriation' (Marx and Engels 2002: 238). And this is precisely what market socialists need to deny, at least insofar as they want to make markets responsible for the allocation of capital and aggregate investment. That is, suppose the allocation of investment were made to depend on the marketmediated private decisions of worker-owned cooperatives. It would follow that some firms accumulate more capital than others, either due to the technical nature of their production process, or due to success in competition. This implies differences in organic composition between $F_{\text {high }}$ and $F_{\text {low }}$, generating transfers of surplus value from the latter to the former. Workers in labour-intensive cooperatives thus become the unhired servants of workers in capital-intensive cooperatives. This is how cooperatives exploit cooperatives through mere exchange. In the absence of democratic control over aggregate investment, abstract subsumption obtains. 


\subsection{How abstract subsumption is distinctive}

Capitalist power characterized by abstract subsumption does not presuppose credit or labour markets. I now take up the differences between abstract subsumption and the other modes of subsumption discussed so far: hybrid, formal, real. Take hybrid subsumption first. There are some relationships between cooperatives that satisfy the usury circuit (first row of Table 2). Vanek's (1970) labour-managed firms, for example, have this form. Vanekian cooperatives are funded by loans from profit-seeking cooperative banks. They are therefore subject not to abstract, but to hybrid subsumption: bank and cooperative occupy the same positions in the capitalist structure as usurer and peasant, respectively. Of course Vanekian labour-managed firms might be an excellent idea, as far as the medium-term freedom and autonomy of producers is concerned. ${ }^{36}$ But that does not implicate these structures any less in hybrid subsumption. By implication, abstract subsumption does not obtain in Vanek-type cooperative relations; it only obtains where a cooperative dominates another in the absence of a credit or labour market.

Now take formal and real subsumption. As I argued above, both of these entail wage-labour; that is, both presuppose a labour market. Abstract subsumption, like hybrid subsumption, does not presuppose a labour market. Suppose there is a system of profit-seeking, workermanaged cooperatives that can freely hire and fire workers. Whenever there is a layoff, the state acts as employer of last resort à la Schweickart (2011). In this institutional setting, all unemployment is frictional and wage-labour is abolished, in the sense that wages and employment are no longer determined by the cost of reproducing the worker (however that cost is determined). Suppose, further, that there is a publicly owned bank that provides loans to cooperatives without extracting surplus value from them. In this institutional setting, there is no usury-type relation between banks and Vanekian cooperatives. For all practical purposes, no capital-positing credit or labour markets exist. There is, by implication, no hybrid, formal or real subsumption of the worker. Yet Robinson-Friday relations of domination manifestly survive; cooperatives now 'valorize their own labour' in the sense that they exploit each other's surplus labour, simultaneously subjecting one another to the law of value. These relations constitute abstract subsumption.

It is worth pointing out, finally, that abstract subsumption, unlike formal and real subsumption, does not presuppose bossing, the domination of producers by bosses. ${ }^{37}$ Abolishing capitalist relations of

36 See Ellerman (2007) for an elegant recent defence of the Vanekian account.

${ }^{37}$ Marglin (1974) claims that bossing is $a$ source of domination under capitalist relations of production. The view defended here is compatible with his view. 


\begin{tabular}{lllll}
\hline & Antediluvian & & & Postdiluvian \\
\hline Subsumption mode & Hybrid & Formal & Real & Abstract \\
Example & Putting-out & Manufacturing & Industry & Cooperatives \\
Transitional & Yes & No & No & Yes \\
\hline
\end{tabular}

TABLE 3. How capitalists dominate.

production abolishes bossing, in the sense that it replaces an intra-firm relation of servitude with an intra-firm relation of equality. In that sense, abolishing bossing might suffice to abolish intra-firm servitude. It does not, however, suffice to abolish inter-firm servitude; that is, it does not suffice to abolish capitalist relations of production.

I conclude that the case for abstract subsumption is defensible. On this view, Marx's account of cooperative workers as 'valorizing their own labour' has critical force. I briefly conclude by discussing some corollaries of the views defended in this paper.

\section{HOW CAPITALISTS DOMINATE}

Capital dominates workers in a number of distinct ways, each falling under the four genera of hybrid, formal, real and abstract subsumption. Both Mercedes-Benz and Uber, for example, exploit their workers. They differ, however, in the mode of dominating power they possess. On the view defended here, subsumption categorizes capitalist exploitation. Table 3 illustrates the relevant positions, along with a historical instance of each.

All four modes of subsumption survive under contemporary capitalism. Take, for example, hybrid subsumption, and more specifically interest-bearing capital, the contemporary incarnation of usury capital. On a widely held Marxist view, credit institutions - hereafter 'banks' do not extract surplus value directly from producers (see, for example, Fine and Saad-Filho 2004: 137, 145). Rather, they extract surplus value from industrial capitalists who, in turn, extract it from wage-labourers. Now take the case of $B$, who is self-employed and has bought a house with a mortgage from bank A. B uses her home office to work; in this sense her office is equivalent to the handicraftsman's workshop. Suppose $B$ valorizes value in the office, just like the handicraftsman valorizes value in the workshop. In lending to B for interest, bank A appropriates newly created surplus value, along the lines represented by the first row of Table 2. Therefore A's relation to B is a capitalist relation of production. The common Marxist view has difficulty making sense of this conclusion. For, by failing to acknowledge nonwage modes of subsumption as 
capitalist, it misconstrues the relationship between A and B as wagelabour 'in disguise' (Fine and Saad-Filho 2004: 140). As I showed in the case of Banaji, above, this is a common misconception, which makes for bad theory and incoherent politics.

The politics of the 'disguised-wage-labour' view are incoherent because its suppressed premiss is that wage-labour constitutes the only source of surplus value (claim (1) is a corollary of this view). It follows that the class of wage labourers is the main object of capitalist exploitation. It further follows that, if this class shrinks - due to, say, deindustrialization, an exogenous increase in self-employment, or spontaneous growth in the 'gig economy' - then the scope of capitalist exploitation shrinks. No Marxist today would accept this anti-Marxist conclusion. But many Marxists who reject it do not realize that it follows validly from claim (1). Hence their appeals to 'forms of disguised wage-labour' and similar gimmicks. Marxists must either drop claim (1), along the lines canvassed above, or accept the anti-Marxist conclusion.

Now consider the implications of abstract subsumption. Defenders of market socialism deny that cooperatives, such as Mondragon's, are instances of capitalist domination (see, for example, Schweickart 2011). That is, whether or not Mondragon-type cooperatives are capitalistically dominated by banks and other credit institutions, they do not themselves exploit, or dominate, other firms. This belief is false. Despite the great benefits that accrue to the advancement of human civilization from democratizing the workplace, cooperatives implicated in capitalist structures are destined to 'reproduce in all cases, in their present organization, all the defects of the existing system'. Absent democratic control over the allocation of aggregate investment, cooperatives can extract surplus value from each other, subjecting each other to the law of value, through mere trade. In this sense cooperatives are, as Marx put it, 'valorizing their own labour', where 'their own' means 'each other's'. This shows how the subsumption of labour by capital lingers in the absence of wage-labour.

\section{ACKNOWLEDGEMENTS}

For helpful comments on earlier drafts of this paper, I would like to thank John Filling, David Leopold, Gil Skillman, Roberto Veneziani, Naoki Yoshihara, two anonymous referees, and the fellow members of the Workers' Democracy Group (Alex Gourevitch, AJ Julius, Lucas Stanczyk, Gabriel Wollner).

\section{REFERENCES}

Banaji, J. 1975. India and the colonial mode of production: comment. Economic and Political Weekly 10 (49): 1887-1889, 1891-1892.

Banaji, J. 2010. Theory as History. London: Haymarket Books. 
Bhandari, R. 2008. The disguises of wage-labour: juridical illusions, unfree conditions and novel extensions. Historical Materialism 16: 71-99.

Brenner, R. 1976. Agrarian class structure and economic development in pre-industrial Europe. Past and Present 70: 30-75.

Brenner, R. 1977. The origins of capitalist development: a critique of Neo-Smithian Marxism. New Left Review 104: 25-92.

Byres, T. 2006. Differentiation of the peasantry under feudalism and the transition to capitalism. Journal of Agrarian Change 6: 17-68.

Callinicos, A. 2014. Deciphering Capital. London: Bookmarks.

Cohen, G. A. 2000. Karl Marx's Theory of History: A Defence. Oxford: Oxford University Press.

DiQuattro, A. 2007. The labor theory of value and simple commodity production. Science and Society 71: 455-483.

Dworkin, R. 2000. Sovereign Virtue. Cambridge, MA: Harvard University Press.

Ellerman, D. 2007. On the role of capital in 'capitalist' and in labor-managed firms. Review of Radical Political Economics 39: 5-26.

Fine, B. and M. Saad-Filho. 2004. Marx's Capital. London: Verso.

Harvey, D. 2010. A Companion to Marx's Capital. London: Verso.

Howard, M. C. and J. E. King. 1975. The Political Economy of Marx. London: Longman Publishers.

Jossa, B. 2012. Cooperative firms as a new mode of production. Review of Political Economy 24: 399-416.

Lebowitz, M. 2010. The Socialist Alternative. New York, NY: Monthly Review Press.

Mandel, E. 1974. An Introduction to Marxist Economic Theory. London: Pathfinder Press.

Marglin, S. 1974. What do bosses do?' Review of Radical Political Economics 6: 60-112.

Marx, K. 1969. Theories of Surplus Value, Volume 1. Moscow: Progress Publishers.

Marx, K. 1972. Theories of Surplus Value, Volume 3. Moscow: Progress Publishers.

Marx, K. 1973. Grundrisse. Harmondsworth: Penguin.

Marx, K. 1976. Capital, Volume 1. Harmondsworth: Penguin.

Marx, K. 1981. Capital, Volume 3. Harmondsworth: Penguin.

Marx, K. and F. Engels. 1962. Werke, Volume 23. Berlin: Dietz Verlag.

Marx, K. and F. Engels. 1988. Collected Works, Volume 30. Moscow: Progress Publishers.

Marx, K. and F. Engels. 1989. Collected Works, Volume 32. Moscow: Progress Publishers.

Marx, K. and F. Engels. 1994. Collected Works, Volume 34. Moscow: Progress Publishers.

Marx, K. and F. Engels. 2002. The Communist Manifesto, ed. G. Stedman-Jones. Harmondsworth: Penguin.

Murray, P. 2004. The social and material transformation of production by capital. In The Constitution of Capital, ed. R. Bellofiore and N. Taylor. New York, NY: Palgrave.

Ogilvie, S. 2008. Protoindustrialization. In The New Palgrave Dictionary of Economics (2nd edn), ed. S. Durlauf and E. Blume. New York, NY: Palgrave Macmillan.

Post, C. 2011. The American Road to Capitalism. Leiden: Brill.

Post, C. 2013. Capitalism, laws of motion and social relations of production. Historical Materialism 21: 71-91.

Rajan, R. and L. Zingales. 2001. The firm as a dedicated hierarchy. Quarterly Journal of Economics 116: 805-851.

Roemer, J. 1982. A General Theory of Exploitation and Class. Cambridge, MA: Harvard University Press.

Roemer, J. 1988. Free to Lose. Cambridge, MA: Harvard University Press.

Roemer, J. 1996. Egalitarian Perspectives. Cambridge: Cambridge University Press.

Schweickart, D. 1996. Against Capitalism. London: Westview Press.

Schweickart, D. 2011. After Capitalism (2nd edn). Lanham, MD: Rowman and Littlefield.

Skillman, G. 1996. Marxian value theory and the labor-labor power distinction. Science and Society 60: 427-451. 
Skillman, G. 1999. Marx's value-theoretic account of capitalist exploitation: non sequitur or tautology? Science and Society 63: 362-372.

Skillman, G. 2007. Value theory vs. historical analysis in Marx's account of capitalist exploitation. Science and Society 71: 203-226.

Sweezy, P. 1942. The Theory of Capitalist Development. New York, NY: Monthly Review Press.

Vanek, J. 1970. The General Theory of the Labor-Managed Economies. Ithaca, NY: Cornell University Press.

Wertheimer, A. 1996. Exploitation. Princeton, NJ: Princeton University Press.

Wolff, R. P. 1985. Understanding Marx. Princeton, NJ: Princeton University Press.

Wood, E. M. 1999. The Origin of Capitalism. London: Verson.

Wood, E. M. 2002. The question of market dependence. Journal of Agrarian Change 2: 50-87.

\section{BIOGRAPHICAL INFORMATION}

Nicholas Vrousalis is Assistant Professor in Political Philosophy at Leiden University. His main research areas are distributive ethics, theories of freedom and the philosophy of social science. Vrousalis' work has appeared in Philosophy and Public Affairs, Journal of Ethics, Politics Philosophy and Economics, Southern Journal of Philosophy and Ethical Theory and Moral Practice. His monograph The Political Philosophy of G.A. Cohen was published by Bloomsbury in 2015. 